\title{
Very Large and Very Small Typhoons of the Western North Pacific Ocean
}

\author{
By Samson Brand \\ Environmental Prediction Research Facility, Naval Postgraduate School, Monterey, California 93940* \\ (Manuscript received 18 October 1971, in revised form 13 May 1972)
}

\begin{abstract}
Twenty-four years of typhoon data (1945-1968) were evaluated to determine if there are geographic and seasonal variations in very large and very small tropical cyclones of typhoon intensity. The results show that there are indeed distinct geographic and seasonal preferences for both large and small storms.
\end{abstract}

\section{Introduction}

Typhoons of the western North Pacific Ocean can develop and exist in a wide spectrum of sizes. The size of these typhoons, measured in terms of the outer closed surface isobar surrounding the tropical cyclone, can vary from a typhoon that would completely cover a good part of the western Pacific to those whose circulations would be difficult to detect on the synoptic scale.

Very large typhoons hamper operations over a vast area, causing operational difficulties as far as $600-800 \mathrm{~nm}$. away from the storm center. For these large systems, typhoon evasion tactics need to begin much sooner than for the average tropical cyclone.

The very small typhoon can become a forecaster's nightmare because of the small scale of this type of system. The "midget typhoons"** tend to be easily missed in the synoptic analyses. Even if satellite photographs should indicate the existence of a small tropical cyclone, the forecaster

* Previously, the Navy Weather Research Facility, Norfolk, Va.

** Arakawa (1952) in a study of small intense tropical cyclones gave them the name "mametaifu" which in Japanese means "midget typhoons". It should be noted however, that Arakawa's "midget typhoons" included tropical cyclones of tropical storm or typhoon intensity. Hawkins and Rubsam (1967) examined in detail a small intense tropical cyclone in the Atlantic, Hurricane Inez (21 September-11 October, 1966) and proposed that small intense storms of hurricane intensity be called "micro-hurricanes". may greatly underestimate storm severity using cirrus canopy/maximum surface wind relationships, since these are based on the more typical size storms.

The objective of this study was to determine if these very large and very small typhoons form and develop in preferential areas and/or months of the year.

\section{Data and method of analysis}

The data used for this study were extracted from a history file of tropical storms and typhoons from 1945-1968 compiled by the National Weather Records Center (Hodge and McKay, 1970) for the Navy Weather Research Facility. Table 1 lists the data sources for this history file.

The history file contains 6-hourly information on such storm characteristics as the location, movement, size, and intensity of all tropical storms and typhoons from 1945-1968.

The 6-hourly values of the mean radius from the center of the tropical cyclone to the outer closed surface isobar in degrees of latitude was used as the measure of the storm size. This size parameter was extracted from the history file and was examined to determine if there were geographic and seasonal preferences for very large and very small tropical cyclones of typhoon intensity.

\section{Discussion of results}

The monthly frequency distribution of typhoon occurrences for storms of all sizes during the years 1945-1968 is presented in Fig. 1. The 
Table 1. Data sources for the history file of tropical storms and typhoons, 1945-1968.

\section{SYNOPTIC CHARTS}

\begin{tabular}{c|l|l}
\hline Period & \multicolumn{1}{|c}{ Preparing Agency } & \multicolumn{1}{|c}{ Location } \\
\hline $1 / 45-12 / 47$ & U.S. Air Force Weather Central & Andrews AFB, Md. \\
$1 / 45-4 / 60$ & U.S. Air Force Weather Central & Tokyo, Japan \\
$7 / 45-12 / 45$ & U.S. Weather Bureau & Washington, D.C. \\
$1 / 54-12 / 67$ & U.S. Air Force, Anderson AFB & Guam, M.I. \\
$5 / 59-12 / 66$ & U.S. Navy, FLEWEACEN/JTWC & Guam, M.I. \\
$1 / 67-12 / 68$ & ESSA, NMC & Washington, D C. \\
$1 / 45-12 / 54$ & U.S. Navy and U.S. Air Force & Various \\
\hline
\end{tabular}

\section{PUBLICATIONS}

Annual Typhoon Reports, Fleet Weather Central/Joint Typhoon Warning Center, Guam, 1953-1968.

Memoirs of the Central Meteorological Observatory, Japan.

A Report on the Typhoons and Tropical Depressions (Philippines), 1947-49, 1951-54, and $1956-58$.

Meteorological Results of Royal Observatory, Hong Kong, 1947-58.

Typhoons of the Western Pacific, August-October 1945, 7th Amphibious Force Aerological Unit.

Typhoon Reconnaissance-Meteorological Squadron ONE-May to November 1946, Office of the Chief of Naval Operations, Washington, D.C.

\section{RECONNAISSANCE DATA}

Air Force Reconnaissance Forms, 1947-68.

Navy Reconnaissance Forms, 1962-68.

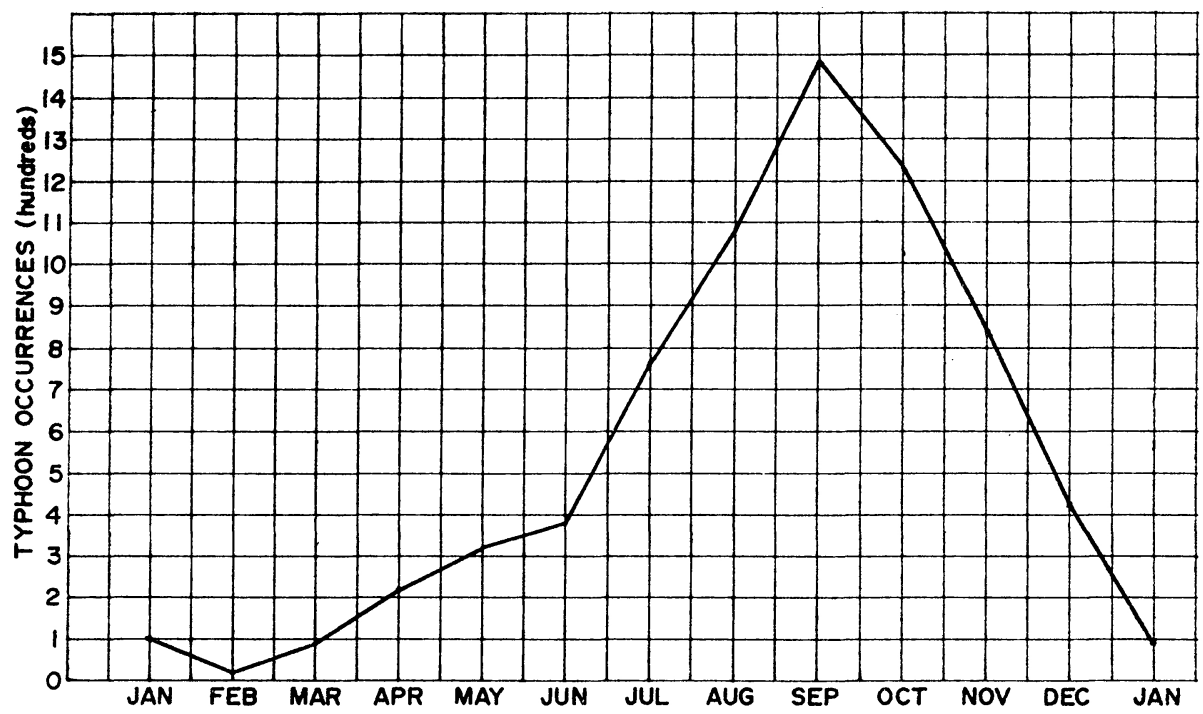

Fig. 1. Monthly frequency distribution of typhoon occurrences (all sizes) for the period 1945-1968. All occurrences, which are based on 6-hourly reports or observations, were at least of typhoon intensity ( $\geq 64$ knots) to be considered. 


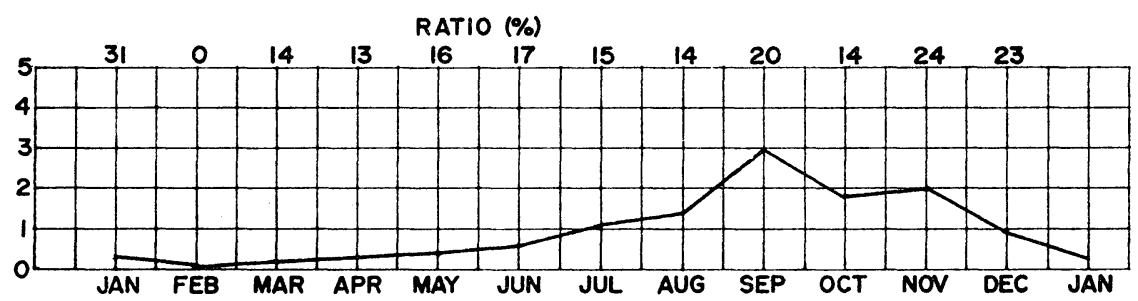

Fig. 2. Monthly frequency distribution of very intense typhoon occurrences $(\geq 120$ knots) for the period 1945-1968. The occurrences are based on 6-hourly reports or observations. The ratio (\%) of very intense typhoon occurrences to total number of typhoon occurrences for each month (Fig. 1) is the number at the top of the graph.

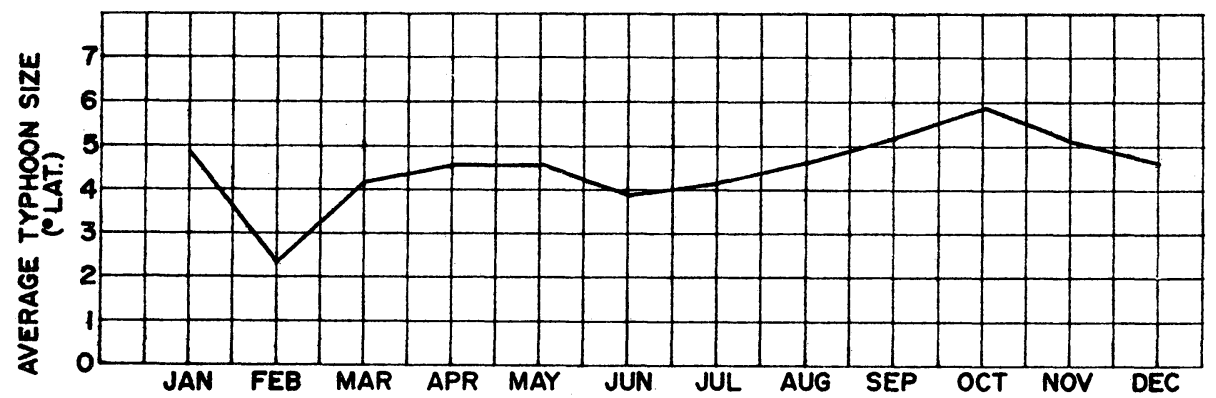

Fig. 3. Distribution of average monthly size of typhoons for the typhoon occurrences shown in Fig. 1. The measure of typhoon size is the mean radius to the outer closed surface isobar in degrees latitude. Average monthly size is the sum of the size of each typhoon occurrence divided by the number of typhoon occurrences for a given month.

number of typhoon occurrences represents the number of 6-hourly reports which indicated a tropical cyclone whose maximum surface wind was 64 knots or greater. Fig. 1 shows a distinct peak in September with a minimum occurring in February.

September is also the month for very intense typhoons, as may be seen in Fig. 2 which presents the number of 6-hourly typhoon occurrences having a maximum surface wind of $\geq 120$ knots. Notice that the number of occurrences almost doubles from August to September.

The monthly ratio of intense typhoon to total typhoon occurrences (percent value given at the top of the graph in Fig. 2) shows a very interesting but unexplained progression throughout the year. That is, if we neglect the small number of total typhoon occurrences in February (see Fig. 1) and consider that the typhoon season extends from March through the following January, we notice that the ratio of intense to total typhoon occurrences is a nearly constant
$15 \%$ through August. However, from September through January the ratio increases significantly, except for a pronounced dip in October.

While September is the month that has the greatest total number of typhoon occurrences as well as the most occurrences of intense typhoons, it is not the month that has the largest typhoons. The distribution of the average monthly size of typhoons (for the total typhoon occurrences depicted in Fig. 1) shows a gradual increase in size from June through October with a decrease occurring in November and December, as may be seen in Fig. 3.

To further examine the monthly size variation of typhoons, a plot was made of the monthly frequency distribution of typhoon intensity occurrences for which the mean radius to the outer closed surface isobar was equal to or greater than $10^{\circ}$ of latitude. These occurrences, denoted as very large typhoons, can be seen in Fig. 4. Also presented (in parentheses below each month) is the number of individual typhoons 


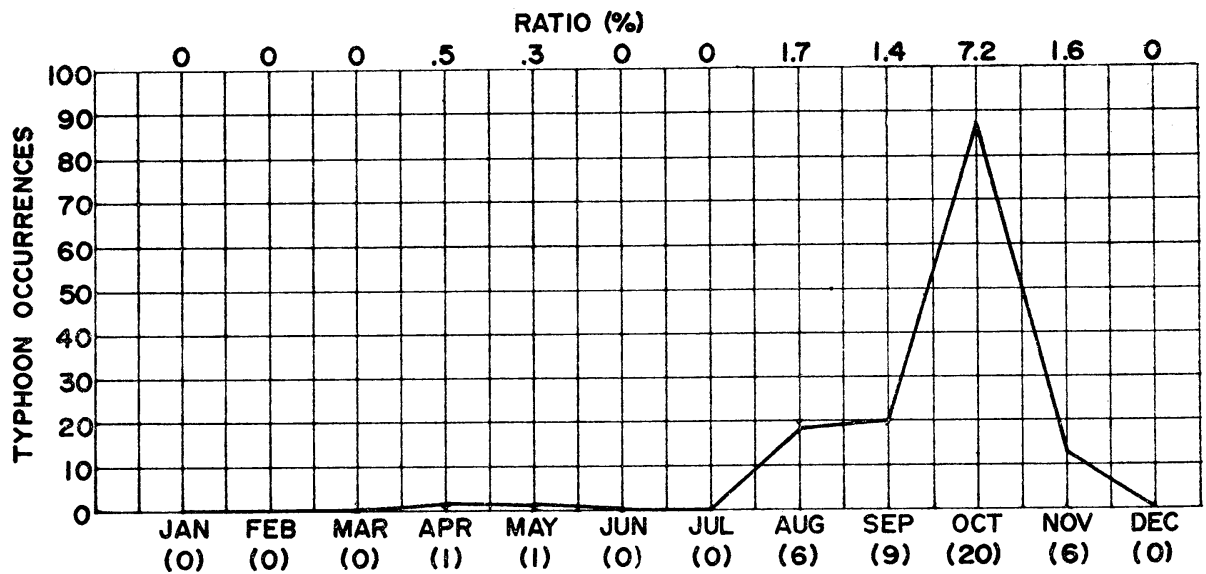

Fig. 4. Monthly frequency distribution of very large typhoon occurrences. All occurrences, which are based on 6-hourly reports or observations (19451968) had to be of at least typhoon intensity ( $\geq 64$ knots) and have a mean radius to the outer closed surface isobar $\geq 10^{\circ}$ latitude to be counted. The number in parentheses below each month is the number of individual typhoons associated with these 6-hourly occurrences. The ratio $(\%)$ of very large typhoon occurrences to total number of typhoon occurrences for each month (Fig. 1) is the number at the top of the graph.

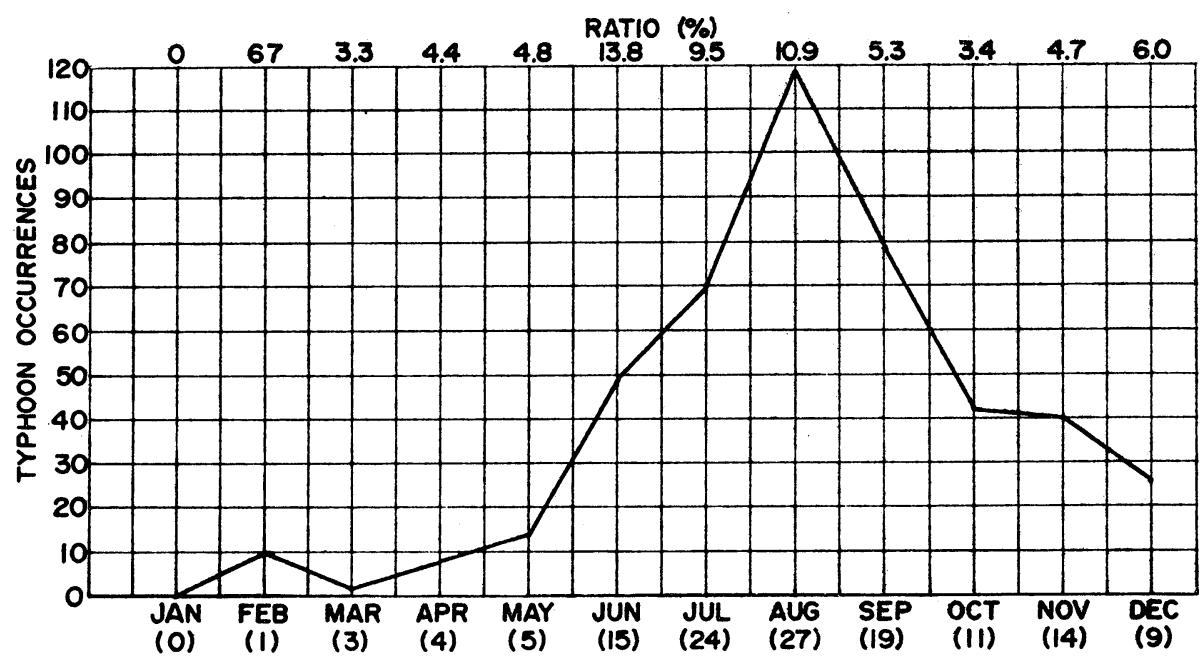

Fig. 5. Monthly frequency distribution of very small typhoon occurrences. All occurrences, which are based on 6-hourly reports or observations (19451968) had to be of at least typhoon intensity ( $\geq 64$ knots) and have a mean radius to the outer closed surface isobar $\leq 2^{\circ}$ latitude to be counted. The number in parentheses below each month is the number of individual typhoons associated with these 6-hourly occurrences. The ratio (\%) of very small typhoon occurrences to total number of typhoon occurrences for each month (Fig. 1) is the number at the top of the graph. 


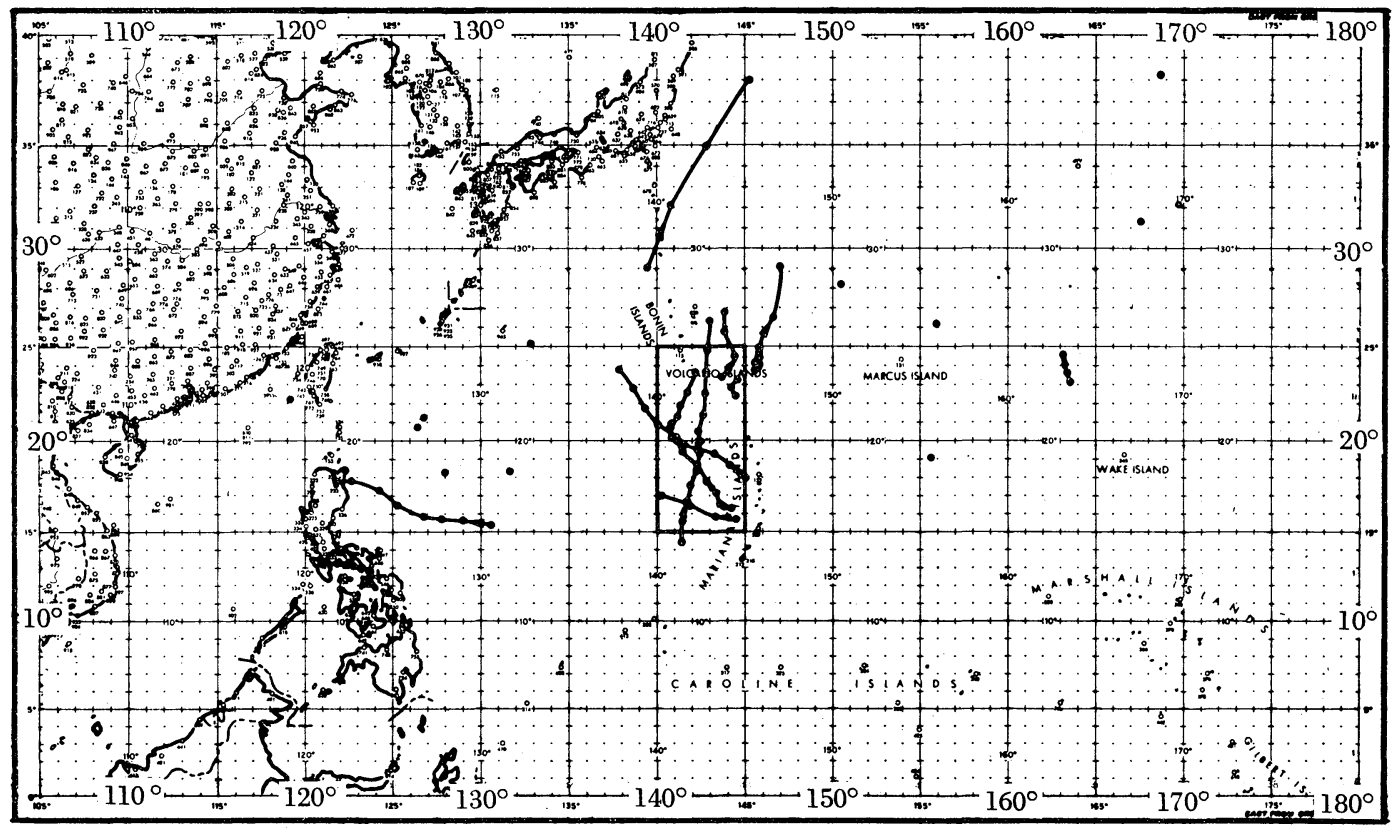

Fig. 6. Typhoon track segments for October typhoons (1945-1968) existing with an average radius to the outer closed surface isobar of $\geq 10^{\circ}$ latitude and a maximum wind $\geq 64$ knots. The single points indicate only one 6-hourly observation fitting the criteria. The rectangular block between $15^{\circ}-25^{\circ} \mathrm{N}$. and $140^{\circ}-145^{\circ} \mathrm{E}$. depicts the preferred area for very large typhoons.

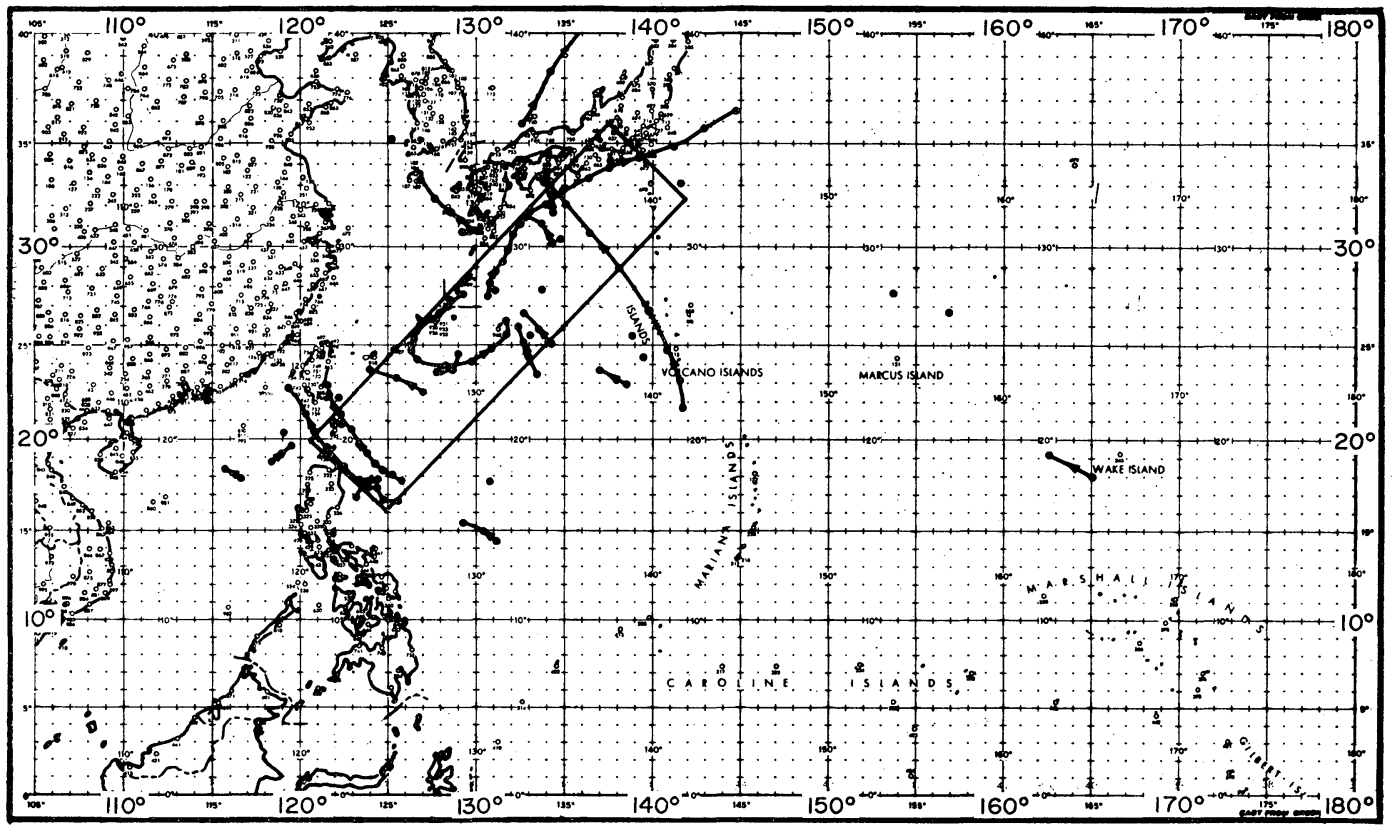

Fig. 7. Typhoon track segments for August typhoons (1945-1968) existing with an average radius to the outer closed surface isobar of $\leq 2^{\circ}$ latitude and a maximum wind $\geq 64$ knots. The single points indicate only one 6-hourly observation fitting the criteria. The rectangular box encloses the preferred area for very small typhoons. 


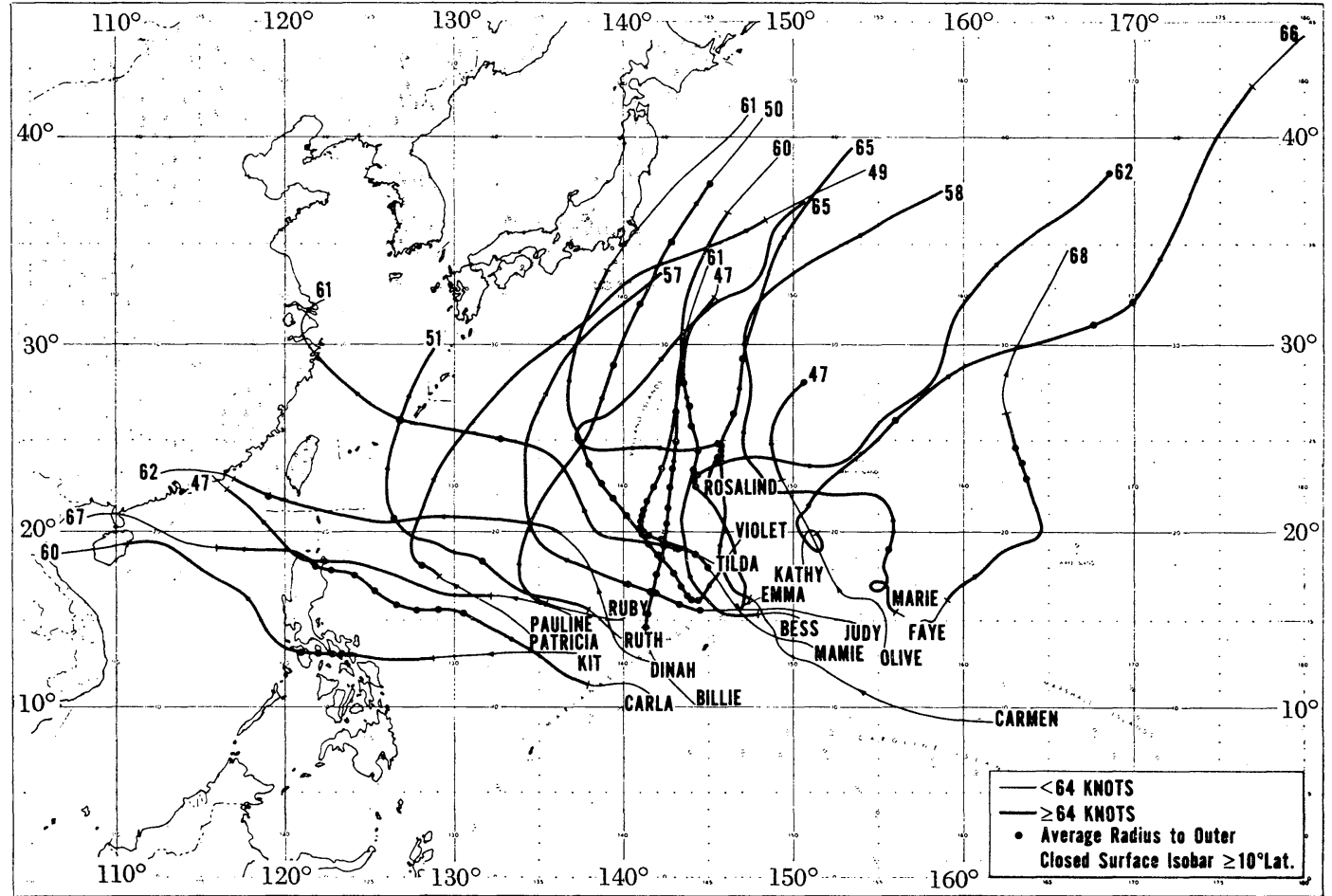

Fig. 8. Typhoon tracks of very large October typhoons (1945-1968). Points indicate when storm met criteria for classification as very large typhoon.

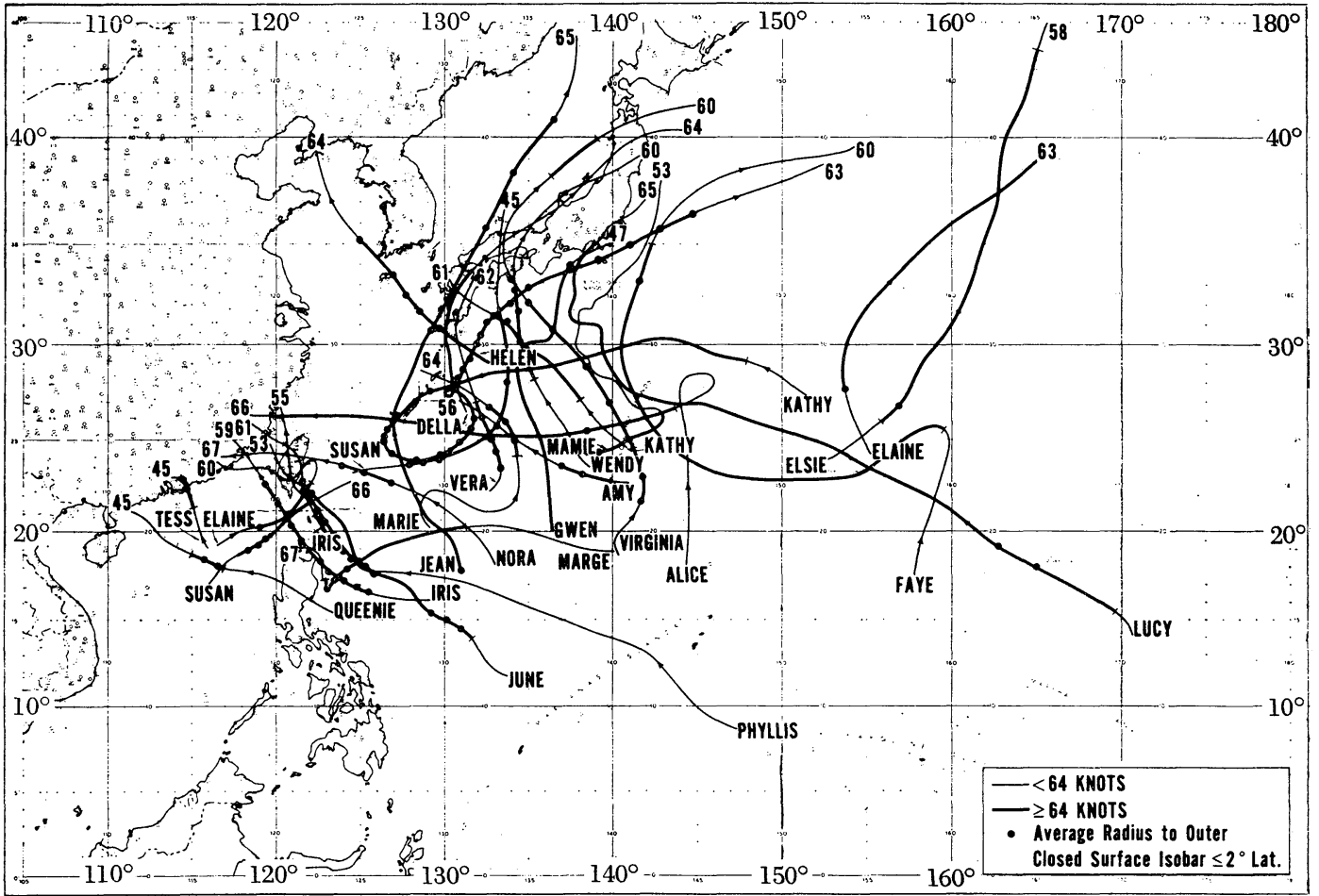

Fig. 9. Typhoon tracks of very small August typhoons (1945-1968). Points indicate when storm met criteria for classification as very small typhoon. 


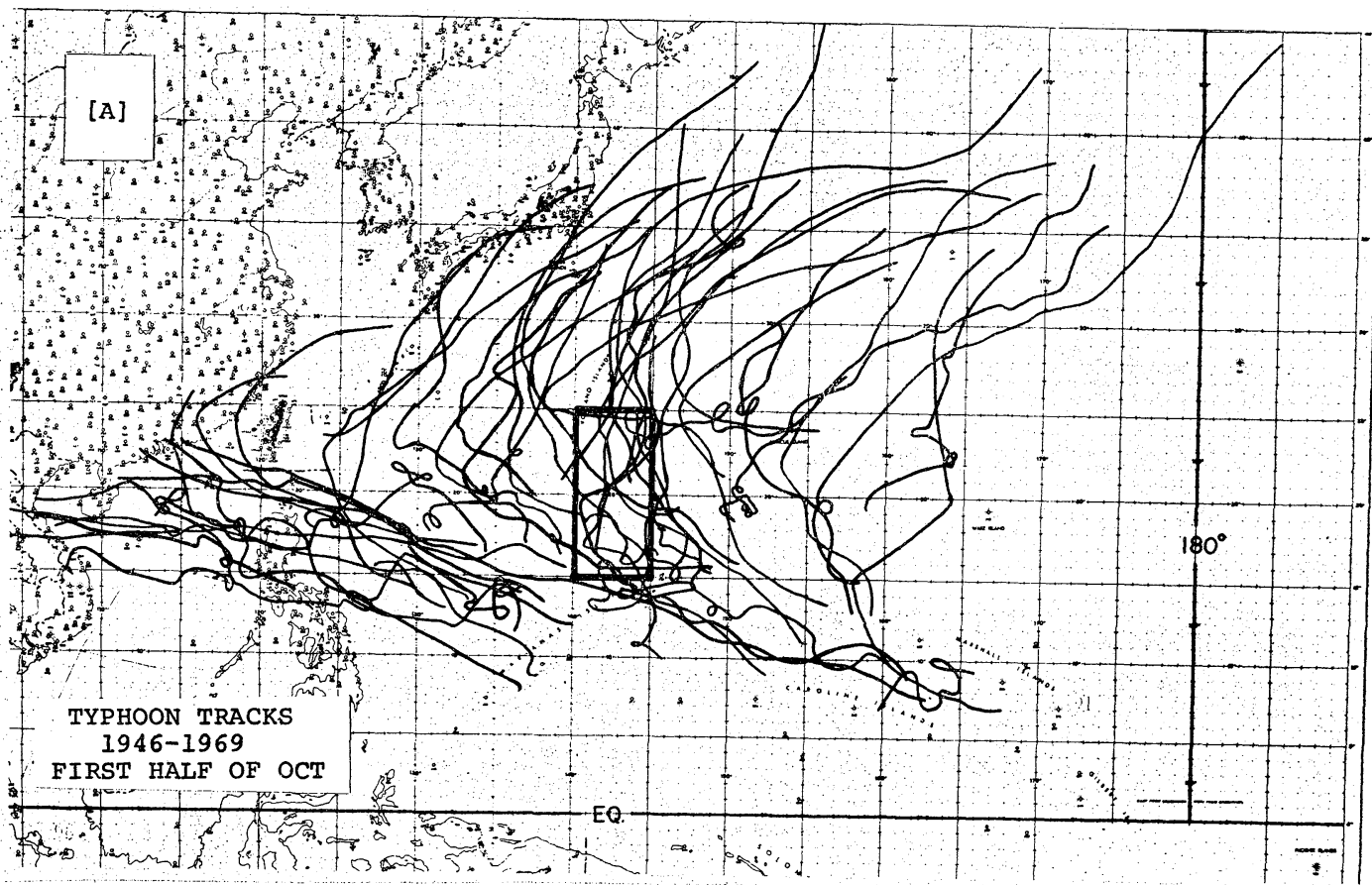

Fig. 10. (a)

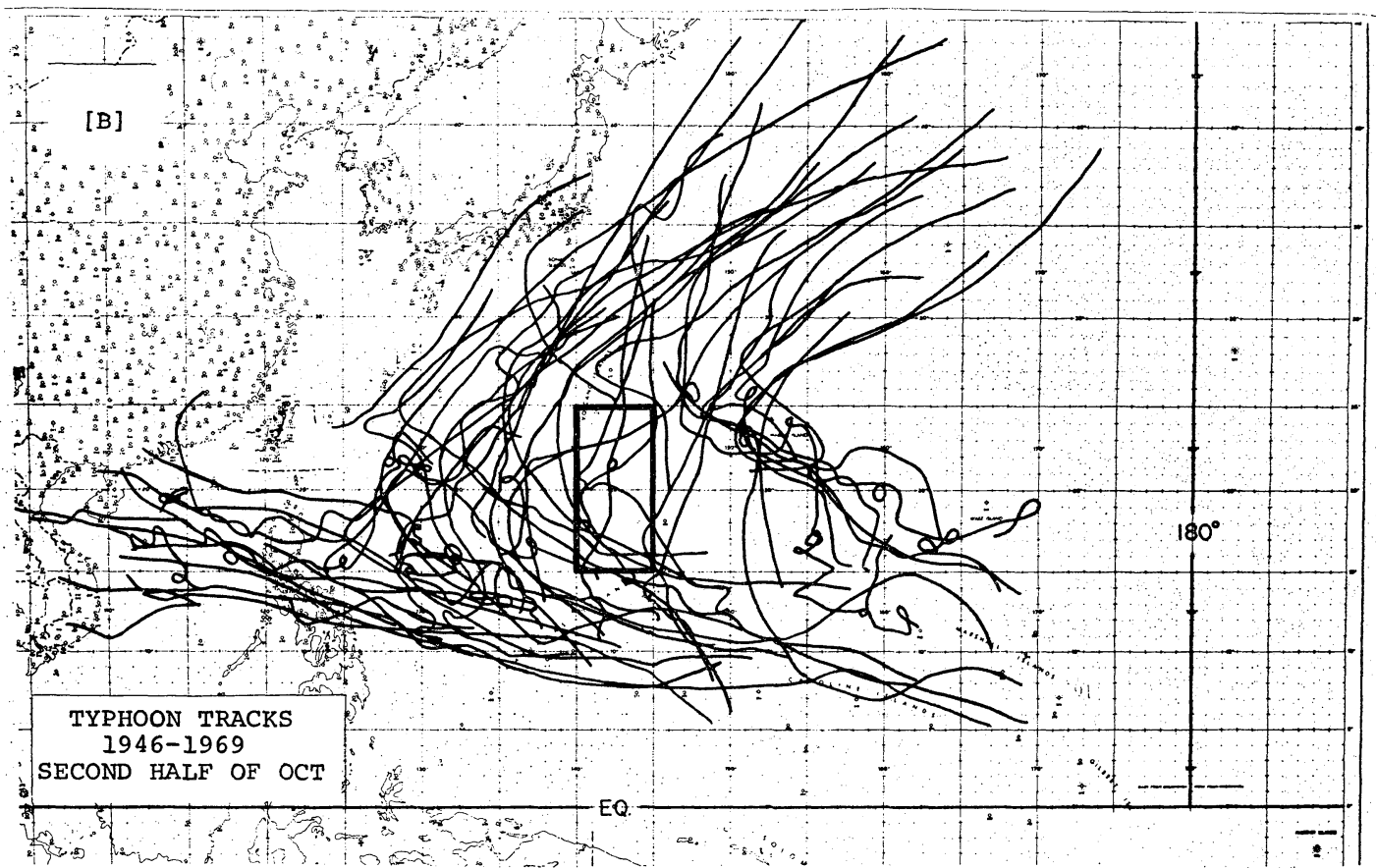

Fig. 10. (b)

Fig. 10. Typhoon tracks (all sizes) occurring during: (a) the first half of October; and (b) the second half of October, during the years 1946-1969 (from Gray, 1971). Typhoons have been placed into half-monthly categories according to the median date of their existence. The rectangular area between $15^{\circ}-25^{\circ} \mathrm{N}$. and $140^{\circ}-145^{\circ} \mathrm{E}$. depicts the preferred area for very large typhoons. 


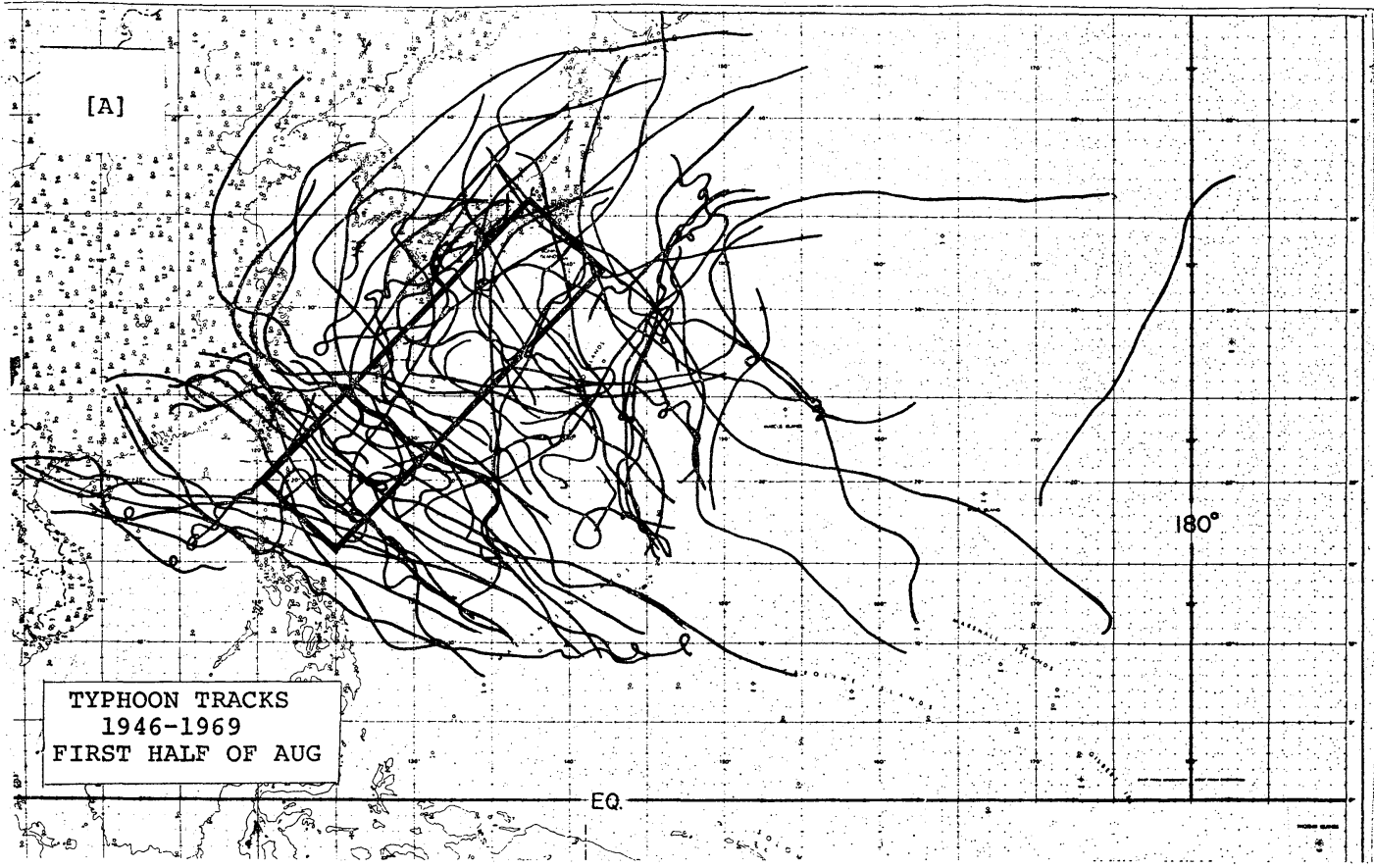

Fig. 11. (a)

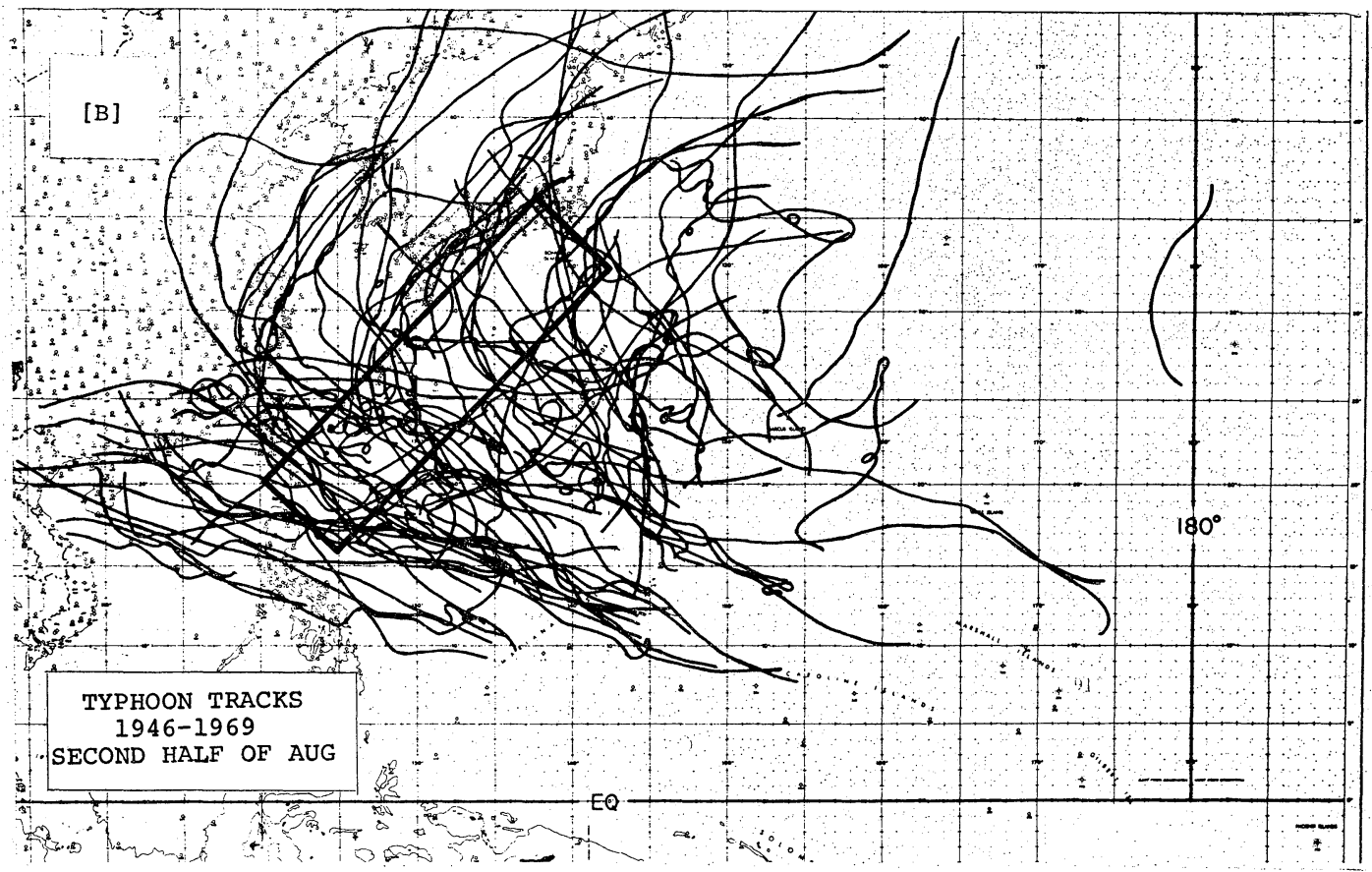

Fig. 11. ( $b$ )

Fig. 11. Typhoon tracks (all sizes) occurring during: (a) the first half of August; and (b) the second half of August, during the years 1946-1969 (from Gray, 1971). Typhoons have been placed into half-monthly categories according to the median date of their existence. The rectangular area depicts the preferred area for very small typhoons. 
associated with these 6-hourly occurrences. October shows a dramatic preference for very large typhoons.

The monthly ratio of the number of large typhoon to total typhoon occurrences (percent value shown at the top of the graph in Fig. 4) indicates a distinct preference for the August through November period, with an extreme peak in October. This October maximum in the percentage of large typhoon occurrences is particularly interesting, in view of the pronounced dip that takes place during October with respect to the percentage of typhoons that are of the intense category.

In a similar manner, an examination was made of very small typhoons. Very small typhoons are defined as those tropical cyclones of typhoon intensity having a mean radius to the outer closed surface isobar equal to or less than $2^{\circ}$ of latitude. The monthly frequency distribution of these very small typhoon occurrences can be seen in Fig. 5. A definite peak exists in August. Even though July has, on an individual basis, almost as many very small typhoons (24 versus 27), August has many more 6-hourly occurrences (119 versus 70). Hence, during August these very small typhoons have a longer duration or existence.

The monthly ratio of the number of very small typhoon to total typhoon occurrences (percent value given at the top of the graph in Fig. 5) shows a peak in August, but notice that an even higher peak occurs in June. The extremely large value for February should be discounted because of the small sample number.

It is evident that both very large and very small typhoons have seasonal preferences. The question then arises as to whether or not there is a geographic preference as well. To determine this, all the positions of the very large typhoon occurrences for that month when they occurred most frequently-October-were plotted on a map of the western North Pacific Ocean. These points when joined gave those segments of the typhoon tracks along which a mature typhoon existed with a mean radius to the outer closed surface isobar equal to or greater than $10^{\circ}$ of latitude. These very large storm track segments and/or points (if there was only one 6-hourly report fitting the criteria) for the years 1945-1968 can be seen in Fig. 6.

The rectangular boxed in area on Fig. 6 shows an apparent preferred geographic location for the existence of these very large typhoon occurrences, which is approximately located between $15^{\circ}-$ $25^{\circ} \mathrm{N}$. and $140^{\circ}-145^{\circ} \mathrm{E}$.

Similarly, a plot was made of all small typhoon track segments and/or points for August-the month when the frequency of very small typhoon occurrences was greatest. This can be seen in Fig. 7. Again, although not as geographically limited as the very large typhoons, a geographic preference exists for these very small typhoon occurrences. The area of preference is the extreme western Pacific Ocean in an area extending from Luzon to Tokyo*.

Fig. 8 shows the complete tracks of the very large October typhoons for which a partial track was plotted in Fig. 6. Similarly, Fig. 9 shows the complete tracks of the very small August typhoons for which a partial track was plotted in Fig. 7. These complete tracks may be compared with the tracks of all typhoons regardless of size for the months of October (Figs. 10(a) and 10(b) and August (Figs. 11(a) and 11(b)) during the years 1946-1969 from Gray (1971).

Fig. 8 indicates that although some of the very large storm occurrences are found with westerly moving typhoons heading toward the Philippines, most of the occurrences are associated with typhoons which in the course of their lifetime tend to recurve or move northerly in the western Pacific between $140^{\circ} \mathrm{E}$. and $145^{\circ} \mathrm{E}$. Fig. 10 suggests that the tracks of typhoons which are "very large", during some portion of their lifetimes, differs little from the tracks of other October typhoons.

A comparison of Fig. 9, showing the complete tracks of very small typhoons, with Fig. 11 indicates that these storms form farther to the north and west than is typical of August typhoons.

Arakawa (1952) in his study of "midget typhoons" of the western North Pacific concluded, after an examination of the small tropical cyclones of August 1950, that these midget storms form after the western portion of the

* It might be pointed out that the size of these small typhoon systems could bias their observed occurrences toward areas where the observational network is better (shipping, aircraft and radar), or where proximity to potentially threatened populaces would cause the possible existence of such storms to receive greater attention. 
North Pacific subtropical High breaks off, moves to the north and intensifies. A wide convergence zone then forms between this High and the North Pacific subtropical High and it is in this zone where these small typhoons form.

It is also interesting to note that the area of preference for these August midget typhoon occurrences is near the region of the warm Kuroshio current, and the two events are probably associated, but it would be premature to link the events quantitatively without detailed case studies. It would also be premature in this observational study to try to explain the October frequency peak and area of preference for very large typhoon occurences, but it could be associated with the fact that many October tropical cyclones tend to recurve further to the East than tropical cyclones in the other months.

\section{Acknowledgements}

The author gratefully acknowledges the many valuable suggestions of Dr. E.C. Kindle and Mr. R.V. Cormier.

\section{References}

Arakawa, H., 1952: Mame-taifu or midget typhoon. Geophys. Mag., 23, 463-474.

Gray, W.M., 1971: A climatology of tropical cyclones and disturbances of the western Pacific with a suggested theory for their genesis/maintenance. Navy Weather Research Facility Technical Paper No. 19-70, 224 pp.

Hawkins, H. F. and D. T. Rubsam, 1967: Hurricane Inez a classic "micro-hurricane". Mariners Weather $\log , 11,157-160$.

Hodge, W. T. and G. F. Mckay, 1970: A computer program to select typhoon analogs and print out their descriptions, including subsequent changes. Nat. Wea. Rec. Cen., First Progress Report, NWRF Project Order PO-90003, $41 \mathrm{pp}$.

\section{太平洋北西域における巨大及び微少台風について}

サムソン・ブランド

（環境予報研究施設, 海軍大学校, モントレー, カリフォルニア）

24年間（1945一-1968）に亘る資料を用い，台風並みの強さをもつ巨大及び微少熱帯低気圧の地理的及び季節的变動 をしらべた。

これらじょう乱の性質については，何れも，地理的及び，季節的傾向があることが，はっきりと認められた。 